\title{
Sprawozdanie z obchodów Jubileuszu 70-lecia Katedry i Kliniki Dermatologii, Wenerologii i Alergologii Gdańskiego Uniwersytetu Medycznego
}

\author{
Gdańsk, 22-24 października 2015 r.
}

Przegl Dermatol 2016, 103, 90-94

Z okazji 70-lecia Gdańskiej Kliniki Dermatologicznej w dniach 22-24 października 2015 r. odbyła się w Sopocie II Konferencja „Dermatologia, Wenerologia i Alergologia". Było to szczególne wydarzenie ze względu na połączenie charakteru naukowego $\mathrm{z}$ obchodami jubileuszu. Przygotowując program, członkowie Komitetu Organizacyjnego gromadzili dokumentację tekstową i fotograficzną do kroniki, która ukazała się w formie książkowej. Wielką pomocą w tych działaniach okazały się teksty źródłowe prof. Henryka Szarmacha, który przez lata wyjątkowo skrupulatnie tworzył kolejne sprawozdania $\mathrm{z}$ działalności Kliniki i zachował unikatowe zdjęcia wykorzystane w kronice. Patronatem honorowym Konferencję objęli: prezydent Gdańska Paweł Adamowicz, prezydent Sopotu Jacek Karnowski, ks. abp Sławoj Leszek Głódź, rektorzy uniwersytetów medycznych w Gdańsku, Łodzi i we Wrocławiu oraz Okręgowa Izba Lekarska w Gdańsku. Konferencja odbywała się pod patronatami naukowymi Polskiego Towarzystwa Dermatologicznego i Polskiego Towarzystwa Alergologicznego. Uczestniczyło w niej ponad 350 lekarzy dermatologów, pediatrów i alergologów, którzy mieli okazję zapoznać się z nowościami dotyczącymi diagnostyki i postępowania w chorobach alergicznych skóry, łuszczycy, nowotworach skóry, trądziku, grzybicach i chorobach przenoszonych drogą płciową. Wybitni i doświadczeni wykładowcy

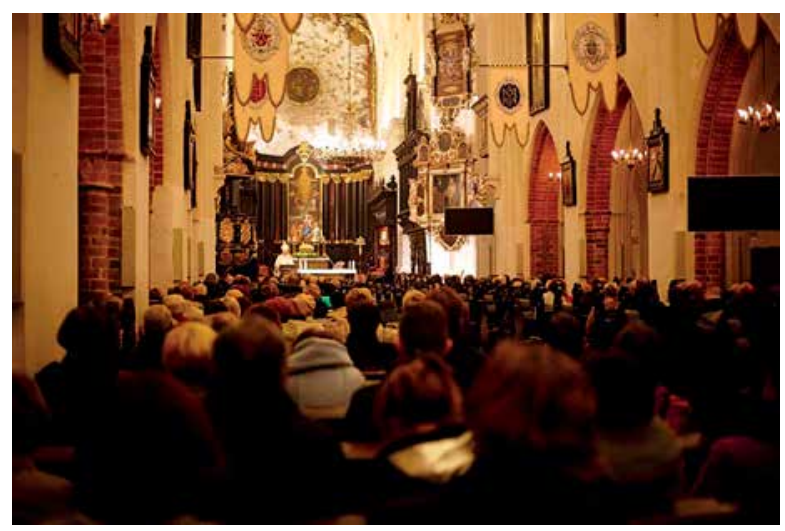

Rycina I. Uroczystość inauguracji Konferencji w archikatedrze oliwskiej zwrócili uwagę na praktyczne zastosowanie przekazywanej wiedzy, uwzględniając przypadki kliniczne.

Ceremonię otwarcia, która odbyła się w archikatedrze oliwskiej, poprzedziła msza św. sprawowana w intencji pracowników Kliniki i gości Konferencji, której przewodniczył bp Wiesław Szlachetka (ryc. 1). Po mszy wszyscy wysłuchali koncertu organowego, a następnie z przewodnikiem zwiedzili katedrę. W refektarzu katedry prof. Roman Nowicki, przewodniczący Komitetu Naukowego i Organizacyjnego, przywitał uczestników Konferencji, a wiceprezydent Gdańska Piotr Grzelak wręczył Medale Prezydenta Miasta Gdańska zasłużonym pracownikom Kliniki oraz zaproszonym gościom (ryc. 2). Ta forma i miejsce inauguracji nadały jej szczególnie podniosły i wzruszający charakter. Część naukowa Konferencji odbywała się w hotelu Sheraton w Sopocie. Oficjalnie otworzyli ją prof. Roman Nowicki (ryc. 3) oraz prezydent Sopotu Jacek Karnowski.

W sesji I (z tłumaczeniem symultanicznym) wystąpili goście zagraniczni. Profesor Vijay Zawar z Indii przedstawił ponad 20 nietypowych przypadków klinicznych, z którymi spotkał się w swojej praktyce dermatologicznej. Profesor Hans Wolff z Monachium omówił zagadnienie chorób włosów u dzieci, zwracając uwagę na ujawniające się w tym okresie charakterystyczne zaburzenia budowy łodygi włosa oraz konieczność ich różnicowania z grzybicami.

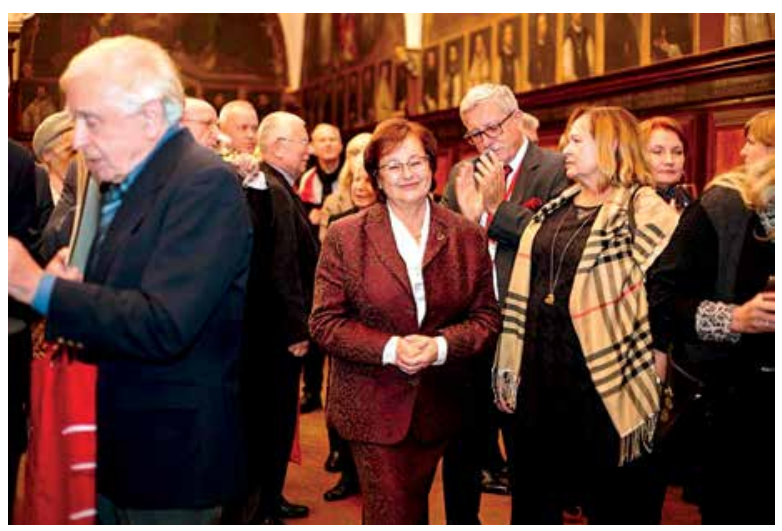

Rycina 2. Profesor Jadwiga Roszkiewicz odbiera Medal Prezydenta Miasta Gdańska 
Kolejny wykład prof. Eckarta Hanekego z Freiburga był poświęcony diagnostyce i leczeniu grzybic paznokci. Autor przedstawił możliwość wykorzystania $\mathrm{w}$ diagnostyce badania histopatologicznego fragmentów paznokcia zawierających podpaznokciową tkankę hiperkeratotyczną, które umożliwia wykrycie dwukrotnie większej liczby przypadków grzybicy w porównaniu z posiewem. W części poświęconej leczeniu prelegent zwrócił uwagę na nowe pochodne azolowe oraz możliwość wykorzystania metody terapii laserowej i fotodynamicznej. Kolejny gość Konferencji, prof. Jan Faergemann z Göteborga, przedstawił rolę drożdżaków z gatunku Malassezia w patogenezie różnych schorzeń dermatologicznych, w tym ciężkich, opornych na leczenie postaci łojotokowego oraz atopowego zapalenia skóry. $\mathrm{Na}$ zakończenie tej sesji prof. Uladzimir Adaskevich z Witebska zaprezentował kliniczny polimorfizm łupieżu różowego, podkreślając duży odsetek pacjentów z nietypowymi obrazami morfologicznymi tego schorzenia, co jest przyczyną licznych błędów diagnostycznych (ryc. 4).

Sesję II dotyczącą wybranych zagadnień wenerologii i dermatologii otworzył prof. Tomasz F. Mroczkowski z Nowego Orleanu, autor znanego wszystkim dermatologom podręcznika poświęconego chorobom przenoszonym drogą płciową. W znakomitym wykładzie przedstawił epidemiologię kiły i rzeżączki w USA, podkreślił narastający problem lekooporności dwoinek rzeżączki na dotychczas stosowane antybiotyki oraz zwrócił uwagę na zmieniający się obraz kliniczny niektórych chorób wenerycznych. Duże zainteresowanie wzbudziła bogata dokumentacja fotograficzna ilustrująca urazy mechaniczne narządów płciowych będące następstwem stosowania różnego rodzaju gadżetów oraz form upiększania tych okolic. Wyjątkowy charakter miał wykład prof. Dmitrija Khvoryka pokazujący historię kiły w Grodnie. Autor przedstawił historyczne dane na temat rozwoju pomocy wenerologicznej w regionie Grodna $\mathrm{w}$ ciągu ostatnich stuleci. Unikatowy materiał zawarty w wykładzie, niedostępny dla polskich dermatologów, pochodził $\mathrm{z}$ dokumentów sięgających początku XVIII wieku, zachowanych w Archiwum Państwowego Obwodu Grodzieńskiego. Bardzo ważne aspekty praktyczne zawierały wykłady prof. Joanny Maj z Wrocławia oraz dr Anny Marzec-Bogusławskiej z Warszawy, w których autorki przedstawiły sytuację epidemiologiczną AIDS w Polsce. Szacuje się, że z wirusem HIV żyje w naszym kraju co najmniej 35 tysięcy osób. Co druga z nich nie wie, że jest zakażona i może nieświadomie zakażać swoich partnerów seksualnych. Istnieje więc pilna potrzeba informowania pacjentów o możliwości testowania w kierunku HIV nie tylko w referencyjnych i komercyjnych laboratoriach, lecz także w punktach konsul-

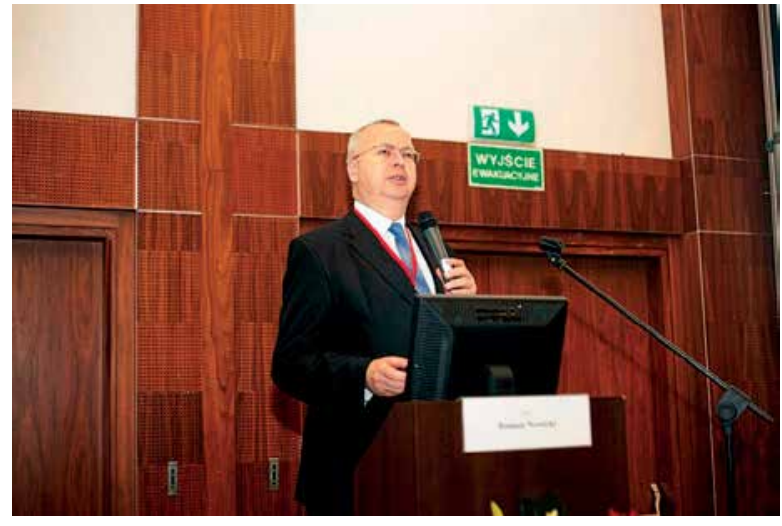

Rycina 3. Profesor Roman Nowicki, przewodniczący Komitetu Naukowego i Organizacyjnego

tacyjno-diagnostycznych (PKD), których lista znajduje się na stronie internetowej Krajowego Centrum ds. AIDS: www.aids.gov.pl. Zgodnie z przyjętymi standardami międzynarodowymi w punktach tych, poza anonimowym wykonywaniem testów, prowadzone jest poradnictwo w zakresie zachowań seksualnych minimalizujących ryzyko zachorowania. Każdego roku w tym systemie na test w kierunku HIV zgłasza się ponad 30 tysięcy osób. Ostatni wykład w części wenerologicznej tej sesji dotyczył szczepień przeciw HPV. Profesor Sławomir Majewski przedstawił sytuacje po 10 latach od wprowadzenia pierwszej szczepionki przeciw genitalnym typom HPV (ryc. 5). Obecnie stosowane są trzy szczepionki: 2vHPV (HPV16, 18), 4vHPV (HPV6, 11, 16, 18) oraz 9vHPV (HPV 6, 11, 16, 18, 31, 33, 45, 52, 58). Badania potwierdziły dużą skuteczność szczepionek 2vHPV i $4 \mathrm{vHPV}$ w zapobieganiu zmianom przednowotworowym i nowotworowym szyjki macicy i zewnętrznych narządów płciowych. Szczepionki 4vHPV oraz 9vHPV mają szersze spektrum działania profilaktycznego, gdyż zawierają dwa komponenty (HPV6, 11) odpowiadające wirusom wywołującym brodawki płciowe, część zmian dysplastycznych szyjki macicy oraz większość przypadków tzw. nawracającej brodawczakowatości dróg oddechowych.

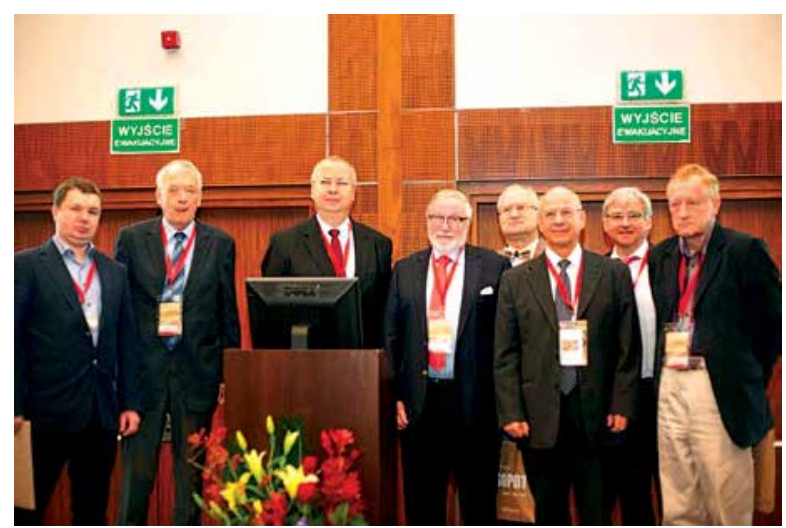

Rycina 4. Profesor Roman Nowicki w otoczeniu zagranicznych wykładowców 


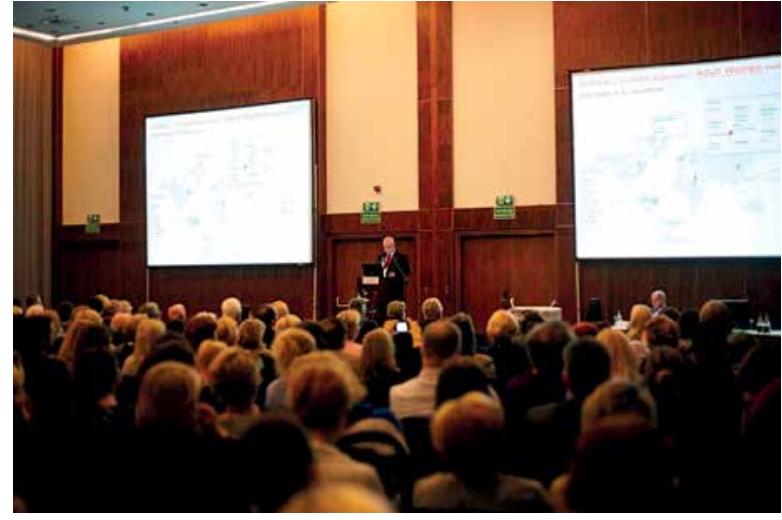

Rycina 5. Profesor Sławomir Majewski w trakcie wykładu

Szczepionki charakteryzują się dużym bezpieczeństwem i w większości krajów rozwiniętych stworzono populacyjne programy szczepień, a ich koszty są refundowane. W Polsce próby wprowadzenia refundacji szczepionek ciągle napotykają na opór organów ustawodawczych. W części dermatologicznej sesji II znalazło się 5 wykładów. Pierwszy dotyczył chorób włosów u dorosłych. Profesor Ligia Brzezińska-Wcisło z Katowic omówiła przyczyny łysienia telogenowego i anagenowego oraz łysienie polekowe, a także przedstawiła zaburzenia strukturalne łodygi włosa oraz metody terapii. Profesor Iwona Flisiak z Białegostoku omówiła aktualne standardy postępowania w zakresie diagnostyki i leczenia boreliozy. Wstępne rozpoznanie tej choroby oparte na kryteriach klinicznych powinno być wsparte wykazaniem swoistych przeciwciał w surowicy za pomocą dwuetapowego postępowania obejmującego wykonanie testu immunoenzymatycznego (EIA), a w przypadku wyniku dodatniego lub wątpliwego dodatkowo badaniem Western-Blot. Leczenie wczesnych stadiów choroby opiera się na 14-21-dniowej doustnej antybiotykoterapii doksycykliną, amoksycyliną lub aksetylem cefuroksymu. W przypadkach neuroboreliozy lub przewlekłego zapalenia stawów chorzy wymagają dożylnego podawania leków, zwłaszcza ceftriaksonu, przez 14-28 dni. Dłuższe leczenie większymi dawkami antybiotyków, leczenie skojarzone dwoma lub więcej antybiotykami, a także terapia sekwencyjna nie znajdują uzasadnienia $\mathrm{w}$ badaniach klinicznych, a więc zgodnie z zasadami medycyny opartej na dowodach nie powinny być stosowane. Trzy wykłady sesji II wygłoszone kolejno przez prof. Katarzynę Woźniak, prof. Cezarego Kowalewskiego z Warszawy oraz prof. Andrzeja Kaszubę z Łodzi były poświęcone problemowi trądziku zwyczajnego i różowatego. Prelegenci skupili się głównie na aktualnych wytycznych dotyczących leczenia tych schorzeń. Terapia trądziku obejmuje różne grupy leków, uwzględnia się w niej zarówno patogenezę choroby, jak i nasilenie zmian skórnych. W trądziku guzkowym lub ropowiczym lekiem z wyboru jest izotrety- noina doustna, która po zastosowaniu pojedynczego cyklu leczniczego w odpowiedniej dawce dobowej i kumulacyjnej umożliwia uzyskanie u 70\% chorych trwałej remisji. Terapia wymaga prowadzenia odpowiedniej diagnostyki laboratoryjnej. Ze względu na teratogenność leku każda kobieta w wieku rozrodczym leczona izotretynoiną musi stosować doustną antykoncepcję co najmniej przez miesiąc poprzedzający rozpoczęcie terapii, przez cały okres leczenia i miesiąc po zakończeniu przyjmowania leku. Nieodłączną częścią leczenia trądziku jest prawidłowa pielęgnacja skóry, polegająca na stosowaniu preparatów nawilżających oraz wspomaganie terapii z wykorzystaniem kwasów owocowych, kwasu salicylowego czy azelainowego. Sposób leczenia trądziku różowatego, zgodnie z międzynarodowym konsensusem, zależy od stadium choroby. W okresie grudkowo-krostkowym polega na stosowaniu ogólnie antybiotyków z grupy makrolidów, tetracyklin lub metronidazolu przez 6-12 tygodni, w dawkach znacznie poniżej antybiotykostatycznych, wykorzystując ich działanie ujemne chemotaktycznie w stosunku do komórek zapalenia, antyoksydacyjne oraz hamujące działanie metaloproteinaz. Niestety w Polsce nie jest dostępny preparat doksycykliny w postaci tabletek $40 \mathrm{mg}$, który jest lekiem $\mathrm{z}$ wyboru do leczenia rosacea w Europie Zachodniej i USA. W zaawansowanych postaciach grudkowo-krostkowych i przerosłych trądziku różowatego należy rozważyć ogólne podawanie izotretynoiny, która przywraca prawidłowe działanie uszkodzonych receptorów Toll-like 2.

Sesja III była poświęcona najważniejszym problemom alergologicznym. W wykładzie Anafilaksja $i$ stany nagłe $w$ alergologii prof. Zbigniew Bartuzi z Bydgoszczy omówił najczęstsze czynniki przyczynowe reakcji anafilaktycznych i zasady postępowania w anafilaksji. Każdy pacjent po przebytej ciężkiej ogólnoustrojowej reakcji anafilaktycznej, bez względu na podłoże immunologiczne i czynnik wyzwalający, powinien zostać zaopatrzony przez lekarza w zestaw leków interwencyjnych: lek przeciwhistaminowy II generacji, doustny preparat glikokortykosteroidu, wziewny, krótko działający $\beta_{2}$-mimetyk oraz adrenalinę w ampułkostrzykawce. Dwa kolejne wykłady w tej sesji dotyczyły problemu pokrzywki. Profesor Bolesław Samolinski z Warszawy przedstawił wyniki badania epidemiologicznego opartego na kwestionariuszu autorskim złożonym z 19 pytań, którego celem było określenie częstości występowania pokrzywki i obrzęku naczynioruchowego w polskiej populacji. Profesor Magdalena Czarnecka-Operacz z Poznania omówiła uaktualniony algorytm leczenia przewlekłej pokrzywki. Prelegentka podkreśliła brak uzasadnienia dla jednoczesnego stosowania różnych leków przeciwhistaminowych drugiej generacji z uwagi na sumowanie się ich dzia- 
łań niepożądanych przy braku dowodów na poprawę skuteczności takiego postępowania. W nowych wytycznych jednoznacznie zostało określone miejsce omalizumabu (trzeci poziom postępowania terapeutycznego) - stosowanego u pacjentów, u których intensywne leczenie przeciwhistaminowe w zwiększonej dawce nie przyniosło pożądanego skutku. W kolejnym wykładzie prof. Radosław Śpiewak z Krakowa przedstawił nowe wytyczne dotyczące wykonywania testów płatkowych opracowane przez zespół ekspertów Europejskiego Towarzystwa Wyprysku Kontaktowego oraz Europejskiej Akademii Alergologii i Immunologii Klinicznej. Sesję alergologiczną zamknął wykład prof. Jerzego Kruszewskiego z Warszawy, który omówił bezpieczeństwo leków przeciwhistaminowych $\mathrm{w}$ aspekcie ich stosowania w ponadstandardowych dawkach.

Na zakończenie pierwszego dnia obrad odbyła się specjalna sesja historyczna "Ocalić od zapomnienia”, która cieszyła się ogromnym zainteresowaniem i zgromadziła pełną salę słuchaczy. W tej wyjątkowej sesji przypomniano sylwetki profesorów tworzących Gdańską Klinikę Dermatologiczną oraz historię polskiej dermatologii. Na wstępie sesji prof. Maria Błaszczyk-Kostanecka z Warszawy przedstawiła najważniejsze osiągnięcia polskiej dermatologii i nazwiska naukowców, którzy na stałe wpisali się do dermatologii światowej. Rektor prof. Wiesław Makarewicz przypomniał wileńskie korzenie gdańskiej dermatologii oraz przybliżył postać prof. Tadeusza Pawlasa, pierwszego kierownika Kliniki Dermatologicznej w Gdańsku. W sesji musiał się znaleźć czas, aby przedstawić imponujące dokonania naukowe prof. Henryka Szarmacha, który pełnił funkcję kierownika Kliniki w latach 1982-1994. Dokonał tego prof. Jerzy Kruszewski, który oparł się w dużej mierze na materiale zgromadzonym przez zmarłego krótko przed Konferencją prof. Wojciecha Silnego.

Z kolei prof. Henryk Szarmach w wykładzie przeplatanym osobistymi wspomnieniami przedsta-

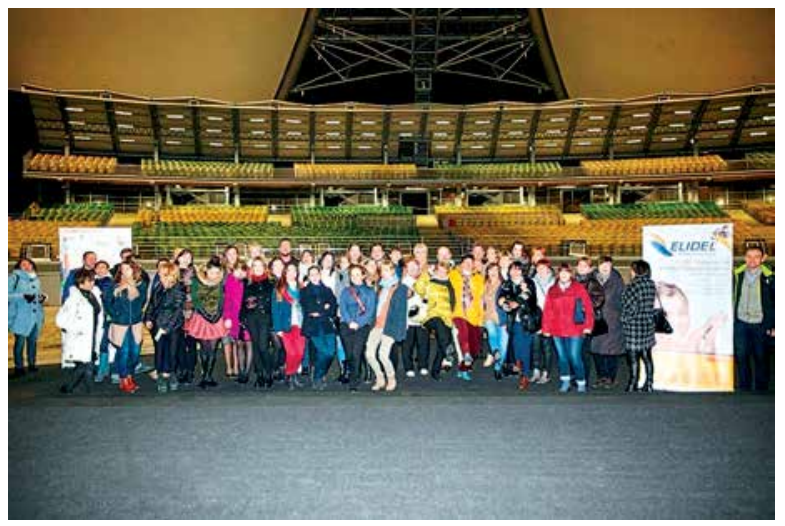

Rycina 7. Spotkanie towarzyskie w Operze Leśnej

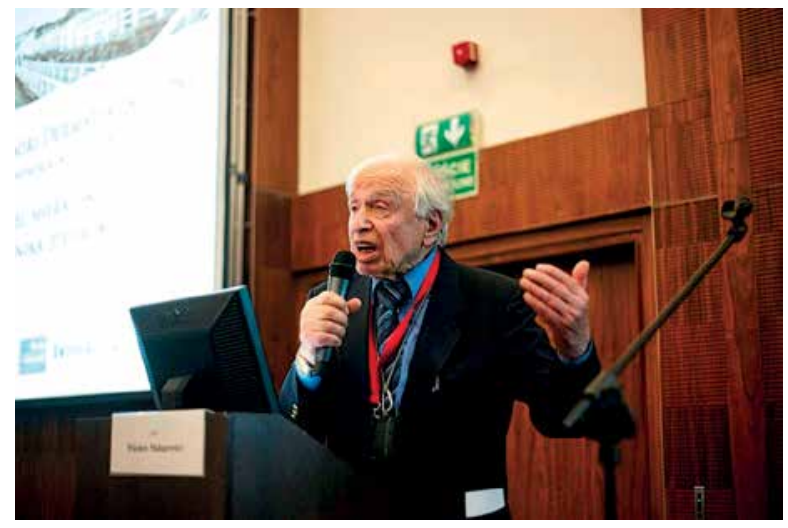

Rycina 6. Profesor Henryk Szarmach wygłasza wykład w trakcie sesji historycznej

wił najważniejsze osiągnięcia swojego nauczyciela, prof. Franciszka Miedzińskiego, kierownika Kliniki w latach 1953-1981 (ryc. 6). Następnie prof. Jadwiga Roszkiewicz w formie bardzo szczegółowego sprawozdania przypomniała rozwój Kliniki w okresie, kiedy nią kierowała (lata 1994-2012). Na zakończenie tej wspomnieniowej sesji obecny kierownik Kliniki prof. Roman Nowicki w wykładzie Historia i teraźniejszość podsumował dotychczasowy dorobek gdańskiej szkoły dermatologii. Bogata dokumentacja fotograficzna ilustrująca wykład wzbudziła ogromne emocje na sali, szczególnie wzruszeni byli ci, którzy poznawali się na zdjęciach sprzed lat. Kończąc wykład, prof. Nowicki podziękował swoim nauczycielom i poprzednikom, a uczestnicy Konferencji uczcili ich owacją na stojąco.

Piątkowy wieczór po zakończeniu Konferencji część uczestników spędziła na spotkaniu towarzyskim w Operze Leśnej w Sopocie (ryc. 7), a pracownicy Gdańskiej Kliniki Dermatologicznej i zaproszeni goście kontynuowali wspomnienia podczas kolacji w Grand Hotelu (ryc. 8). Tu pojawiły się mniej oficjalne wystąpienia prof. Henryka Szarmacha, prof. Waldemara Placka i prof. Adama Włodarkiewicza, którzy przypominali zarówno naukowe, jak i kuluarowe oraz towarzyskie wydarzenia z życia Kliniki.

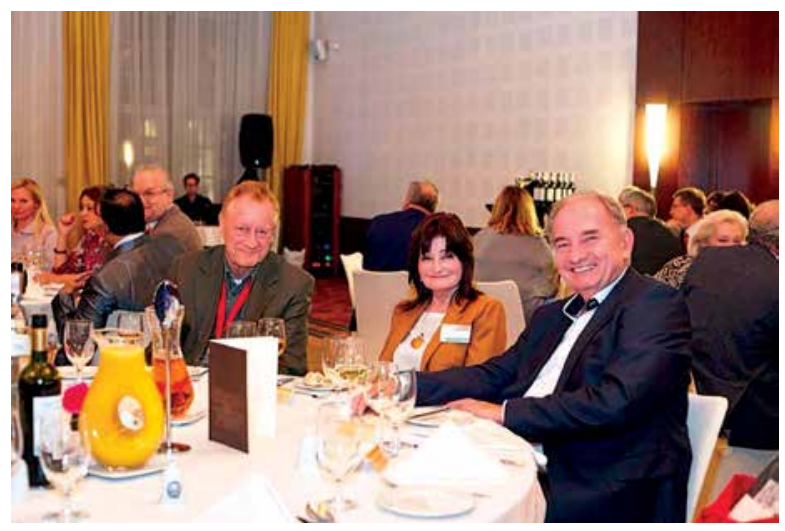

Rycina 8. Wieczór wspomnieniowy w Grand Hotelu 
Obrady drugiego dnia Konferencji rozpoczęła sesja $\mathrm{V}$, poświęcona przypadkom klinicznym, które zademonstrowali młodzi pracownicy Kliniki Dermatologii w Gdańsku. Najwięcej emocji wzbudził przypadek jatrogennego zespołu Cushinga u dziecka, wywołany miejscowym stosowaniem glikokortykosteroidów. Pomimo szerokiej edukacji prowadzonej przez dermatologów niepożądane odczyny wywołane tą grupą leków obserwowane są w codziennej praktyce. Drugim przypadkiem szczególnie wartym udokumentowania jest okołonaczyniowe martwicze zapalenie powięzi. Dzięki szybkiej diagnostyce i wdrożeniu właściwej terapii udało się uratować pacjentkę z tym rzadkim schorzeniem, obciążonym fatalnym rokowaniem.

Sesję VI Choroby skóry - aktualne problemy rozpoczęła prof. Lidia Rudnicka z Warszawy wykładem na temat aktualnych możliwości diagnostycznych i terapeutycznych liszaja płaskiego mieszkowego. W kolejnym wykładzie prof. Witold Owczarek przedstawił aktualne zalecenia dotyczące rozpoznania i leczenia czerniaka. W rozpoznaniu tego nowotworu nadal największe znaczenie ma badanie kliniczne, uzupełnione o nieinwazyjne badania dodatkowe (dermoskopia lub wideodermoskopia). Podstawą rozpoznania jest badanie histopatologiczne całej wyciętej zmiany. Obecnie terapia uzupełniająca po leczeniu chirurgicznym jest stosowana tylko w wybranych przypadkach. W uogólnionym czerniaku stosuje się immunoterapię za pomocą przeciwciał monoklonalnych anty-CTLA4 lub anty-PD-1 oraz leczenie ukierunkowane na cele molekularne (inhibitory BRAF, MEK). Dwa wykłady w tej sesji były poświęcone terapii łuszczycy. Profesor Hanna Wolska podkreśliła ważną rolę tradycyjnych metod leczenia tej choroby w sytuacji, gdy wysokie ceny leków biologicznych i bardzo restrykcyjne metody kwalifikacji do programów lekowych powodują, że nie są one dostępne dla wszystkich pacjentów, nawet tych, którzy teoretycznie bezwzględnie się do nich kwalifikują. Profesor Joanna Maj zwróciła uwagę na ograniczony dostęp pacjentów z łuszczycą do światłoterapii, co wynika $z$ niedoszacowania tej procedury przez NFZ, niedostatecznej liczby skutecznych preparatów zewnętrznych w dostępnej cenie, a także braku skutecznych leków małocząsteczkowych, poza cyklosporyną i metroteksatem.

W ostatniej VII sesji zaprezentowali się samodzielni pracownicy Klinki Dermatologii w Gdańsku: dr hab. Magdalena Lange (mastocytozy), dr hab. Aneta Szczerkowska-Dobosz (łuszczyca), prof. Małgorzata Sokołowska-Wojdyło (chłoniaki pierwotnie skórne) oraz dr hab. Wioletta Barańska-Rybak (peptydy przeciwdrobnoustrojowe). Sesję zakończyły wykłady prof. Romana Nowickiego oraz dr Aleksandry Wilkowskiej przedstawiające aktualne możliwości leczenia atopowego zapalenia skóry z uwzględnieniem aktywnych emolientów nowej generacji.

Gdy program naukowy został zrealizowany, prof. Roman Nowicki podsumował i zakończył Konferencję. Podziękował wszystkim wykładowcom, uczestnikom oraz sponsorom, a prof. Eugeniusz Baran zaintonował „Sto lat” na cześć pracowników Kliniki z okazji obchodzonego jubileuszu, które sala podjęła z entuzjazmem.

Pomimo ogromnej liczby zjazdów, sympozjów i konferencji, niewiele jest wydarzeń naukowych, w których możliwa jest międzypokoleniowa wymiana doświadczeń naukowych i życiowych. W takich chwilach nasuwa się refleksja, że powinniśmy uważniej słuchać naszych nauczycieli wypowiadających opinie nie zawsze zgodne $\mathrm{z}$ aktualnie obowiązującymi konsensusami, ponieważ dopiero po latach okazują się one prorocze.

Elżbieta Grubska-Suchanek Katedra i Klinika Dematologii, Wenereologii i Alergologii Gdański Uniwersytet Medyczny 